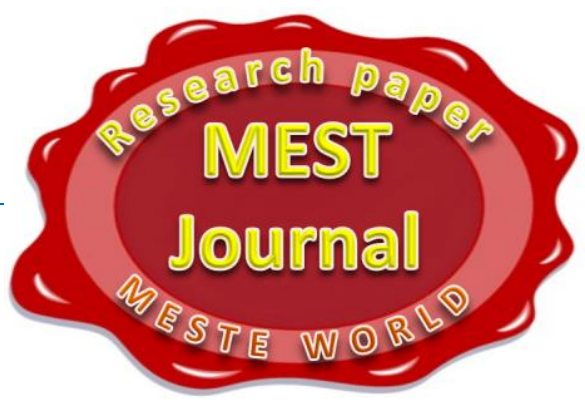

\title{
INTEGRATION OF EDUCATION, SCIENCE AND PRODUCTION IN SYNERGETIC PARADIGM OF PUBLIC MANAGEMENT
}

\section{Larysa Emelyanenko}

Vadym Hetman Kyiv National Economic University, Kyiv, Ukraine

\section{Tetiana Shkoda}

Vadym Hetman Kyiv National Economic University, Kyiv, Ukraine

OMESTE

JEL category: I20, 030, L60

\begin{abstract}
The article aim is to justify national priorities of integration processes activation in science, education and production that is important to consider in the synergetic paradigm of public management in Ukraine at the current stage of new challenges of globalization and the need to stabilize the economic development on innovative principles in the context of competitiveness. Integration is considered from the standpoint of a specific type of organizing the social interaction forms of modern spheres of science, education, production and adapting business entities to innovations in the context of qualitatively new joint structures, modernizing partnerships relations, effective functioning of which is accompanied by a synergetic effect. Based on the Global Competitiveness Index of the World Economic Forum integration of science, education and production in Ukraine in the international dimension is analyzed. There are determined the negative factors that impede the positive development of the national integration processes in Ukraine. The basic modern challenges and preconditions of deepening scientific, educational and productive interaction in Ukraine are formulated. It is proved the objective necessity of using a synergetic approach to strategic public management in modern conditions of openness and nonlinearity of the Ukrainian national economy development, irreversibility of institutional changes and macroeconomic instability. The authors have developed the system of public management of balancing human and technological development of Ukraine, innovative tools of which are based on traditional methods of justifying the strategic program-targeted direction priorities.
\end{abstract}

Keywords: Integration, science, education, production, synergetic paradigm, public management

\section{INTRODUCTION}

In the modern dynamic world, the economic

The address of the corresponding author: Tetiana Shkoda

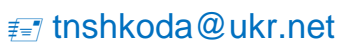

growth is not possible without the innovative development based on advanced scientific achievements. With the growth of international competition success of socio-economic development is guaranteed only to those states that can provide effective realization of human potential. International technological and scientific 
exchange, transfer of intellectual potential is one of the hallmarks of our time.

Integration of science, education and production is of great importance for the national economy competitiveness and the state as a whole. It is important for Ukraine to revive demand for science as the basis for the competitiveness of the national economy. It is necessary to combine education, science and innovations by expanding the research sector in higher education institutions.

Development of integration of education, science and production will accelerate modernization of the scientific and educational spheres and reduction of at least a part of related costs (including social costs), the more efficient use of budget funds and state property, improvement of the age structure of employees and quality of education, growth of innovation activity. Quality of new generations of professionals that come into branch and academic research institutes determines the level of these scientific advances and their potential innovation capacity. Integration not only promotes the university lecturers' active participation in scientific and research works (R\&D), but also allows creating professional and educational programs and providing laboratory equipment that meets the current state of science. Thus, for realizing modern, more complex models of integration and adequate to them financial and economic mechanisms the substantial adjustment of legislative norms and the state support of the integration process are necessary.

\section{THEORETICAL FOUNDATIONS OF INTEGRATION OF SCIENCE, EDUCATION AND PRODUCTION}

Issues of integration of science, education and production in the economic, philosophical, legal, historical aspects are considered in the scientific works of such authors as: Amosha, Vishnevskiy \& Zbarazska (2012), Roco \& Bainbridge (2013), Bavykhin (2003), Bazhal (2009), Fey \& Birkinshaw (2005), Fedulova (2009), Heyets \& Semynozhenko (2006), Kostyuk (2011), Twiss (1980) and others. Despite the considerable number of publications on the researched subject, its complexity and novelty, many methodological issues remain unresolved. It is acquired the particular relevance of problem issues of identifying the fundamentally new requirements for scientific and educational organizations as active participants in the innovation process, effective stimulators of the productive forces, which leads to justification of the priorities of improving the current forms of integration and implementing the new promising models of cooperation of science and education with production.

Investigation of the "integration" concept in the economic aspect, definition of reasonable limits of interaction between science and education as equal partners allowed to specify the nature of integration on areas of science and education as a set of relationships between scientific and educational organizations that interact as a part of the integration structure or on a contractual basis for establishing sustainable relationships, in order to harmonize interests, achieve the additional effect of joint activity and relationships with production and public authorities.

Integration as a specific type of social interaction and the process of productive, socio-economic, administrative and political adaptation of the economy different sectors subjects to innovations should be considered from the standpoint of the formation of a qualitatively new integrated structures with the accelerated path of development, which is usually accompanied by occurring certain emergent (synergetic) effect of providing the excess of the result of collective (joint) operation of the new structures individual elements over the sum of their individual (autonomous) actions by using the relationships, mutual reinforcement of different activities. An important prerequisite for appearance of synergetic effects is a conscious collective activity of the innovation activity subjects, behaviour of which is determined by a complex of endogenous and exogenous factors.

Research of interaction of modern education, science and production has a very important scientific and socio-economic importance. It is essential for establishing the effective regulation of their mutually conditioned relations.

As we live in the age of the society innovative development, the system of higher education is facing new challenges. The traditional knowledgeeducation model is gradually replaced by a competence model, which is filled with the activity beginning and promotes the comprehensive 
development of the individual, successful in society (Kostyuk, 2011).

The root cause of such fundamental changes in the education sector is a scientific and technological revolution (STR), marked the second half of the past $X X$ century. The main features of the STR are the following (BulanovaToporkova, 2002):

- fusion of scientific and technological revolution;

- scientific discoveries become immediately the basis of new technologies;

- transformation of science into a productive force;

- the system automatization of production;

- replacement of direct human labour by materialized knowledge in production;

- appearance of a new type of an employee with a qualitatively new level of training and thinking;

- transition from extensive to intensive production.

But the main feature is that STR was formed on the basis of deep systemic linkages of science, technology, production and the resulting radical revolution in the productive forces of society under the defining role of science.

One of the major consequences of the STR is transformation of the individual, his role in the scientific and technological progress and the STR negative consequences elimination through creation of a new living environment and development of other needs, which in turn determined the choice of a new, individualoriented educational paradigm.

Features of the modern science development (Bulanova-Toporkova, 2002), which main principles are integration and a synergistic approach, help to understand patterns and prospects of the modern education development as a key element of one of the STR subsystems.

It is generally accepted the socio-economic importance of education and its role in scientific and technological progress, the spiritual life of society, development and the economy qualitative improvement. In the modern conditions of forming an innovative economy competition in the economic sphere comes down to competition in the field of science and technology and, as a result, to competition in preparing and organizing the use of qualified personnel. Today, every country in order to take a decent position on the world scene and ensure the high economic growth needs to make large investments in education, training and extensive training, expanding access to knowledge.

Education is the widest sphere of social activity. And it should develop faster than the economic activity.

Nowadays, large manufacturing companies need only highly qualified employees who are ready to intensive intellectual work. For this reason, there is a gap in the incomes distribution between population groups of different qualifications (Bavykhin, 2003). It is more difficult to find lowqualified jobs in the developed countries, because such productions are removed to the developing countries with the cheap labour sources. To solve this problem, the developed countries have gone through a major expansion of advanced training courses, retraining, and proposals of alternative jobs. However, under such conditions there are visible discrimination and presence of social barriers. It interferes with the process of obtaining knowledge by a part of population and leads to the social tensions enhancement and a sharp increase in income differentiation, and hence to social conflicts. Thus, an indicator of socioeconomic development of the state is the common to all opportunities to receive, apply and develop knowledge.

Today in the economy of the leading countries there is growing demand for a highly qualified, highly intellectual employee who has received fundamental education. Such an employee is able to think creatively and make non-standard, highperformance solutions.

Also, since the 60 -ies of $X X$ century, education is considered as one of the most important sources of increasing the productivity of labour. For example, T. Schultz considered education as an independent factor of growth (Schultz, 1960), while E. Denison - as the qualitative characteristic of the labour factor (Denison, 1967).

It should be noted that, since the economic growth affects the level of employees' education, respectively, then it influences the productive activity of the enterprise. 
Also, education not only turns a man into a more productive employee, but also develops its business and organizational skills. In the economic literature, this phenomenon is called the "distribution effect" of education: "working efficiency is related to the ability to perform a certain number of tasks; distribution effectiveness is associated with the ability to make right decisions" (Chiswrok, 1974). Rapid implementation of innovations improves the enterprise effectiveness, and therefore stimulates competition in the industry, thereby the productivity of labour is increased in society and the economic growth is stimulated.

As to the authors' point of view, contribution of education to the economic growth of the industrial enterprise can be considered in three main directions:

1. providing the enterprise employees with receiving already accumulated knowledge;

2. promoting an employee to obtain new knowledge;

3. accompanying the knowledge production required to work in the production during the period of scientific and technical progress.

It is also necessary to take into account the fact that in recent years the system of production and transmission of knowledge has dramatically changed. In addition, the volume of existing knowledge and information has significantly increased.

Nowadays, it is impossible for the 5-6 years to prepare a person for professional activity for the whole life, because every year theoretical $5 \%$ and $20 \%$ of professional knowledge is updated. For example, the unit of measurement of aging new knowledge of a specialist adopted in the United States, the so-called "half-life of competence" (competence period of decline by $50 \%$ ) as a result of new information shows that for many professions that threshold occurs in less than five years (Fedulova, 2009). To solve this problem, it is possible only with the use of the concept of lifelong learning (OECD, 1996), where each successive level of education is a continuation of the previous one.

It is important to note the need for high performance equal to the three main levels of education, i.e. primary, secondary and higher education. As the developed countries experience shows that for creating the social conditions, which make possible "technological breakthrough" and exit of the country to a new economic level, are important results and quality of all three levels (Ivanov, 2002):

1. resistant skills of education and accounts produced in primary education;

2. general worldview and the mechanisms of thinking, as well as the technical and organizational skills, which an average level gives;

3. cognitive skills and the ability of thinking to conduct researches, which is given by the higher education system.

It should be noted that the modern education and production integration takes place mainly at the level of higher education.

Education, as a system at the current stage of development, should be realized through the systemic knowledge that is necessary for developing holistic, systemic thinking. Such knowledge can be obtained in the form of synergies from integration of humanitarian, fundamental and engineering sciences. And it is necessary to focus on the global level of science.

Today, thanks to the penetration of the synergetic concept into education, there is a growing interest in issues related to management of integration processes in the educational institutions of high school through the use of the ideas of synergy in order to achieve the necessary competitive advantages by consolidating material and technical, financial, scientific and technical, and human resources and recovering the desired synergistic effect. The organizational and economic mechanism of implementation of the new synergetic concept aimed at the priority and advanced development of the education system and activization of innovative activities of higher educational institutions can become the system integration of academic science, educational institutions and specialized business structures based on the concept of a cluster as a promising modern tool of innovation management in the context of administrative and territorial education. 


\section{THE STATE OF EDUCATION, SCIENCE AND PRODUCTION INTEGRATION OF UKRAINE IN THE INTERNATIONAL DIMENSION}

The current development of the global and national economies is largely determined by its ability to produce, use and commercialize new knowledge and technologies. Innovations are the key factor of the economic development, providing more than $50 \%$ of the global economic growth.

Nowadays, Ukraine is represented in several international indexes that assess the scientifictechnological and innovative competitiveness of countries and perform their ranking. They include the Global Innovation Index (GII), the Innovation Efficiency Ratio and the Knowledge Economy Index of the World Bank Institute (Grodsky, 2012).

On the authors point of view, integration of science, education and production in Ukraine is best illustrated by the pillar "Innovations" (Table. 1) in the context of subindexes "Universityindustry collaboration in R\&D", and "Government procurement of advanced tech products“. The pillar "Innovation" provides an opportunity to analyze the ability of the state to restructurization of the economy by using its own scientific institutions, intellectual potential of employees, government support and effective cooperation of universities with business.

During the period from 2010 to 2014, Ukraine's position for the analysed pillar "Innovation" has steadily deteriorated. It dropped from $63^{\text {rd }}$ position (3.11 points) in 2010-2011 years to $93^{\text {rd }}$ position (3.03 points) in 2013-2014 years. Only in the last period (2014-2015 years), the Ukraine's position has slightly improved. And now the country takes $81^{\text {st }}$ position, which is equal to 3.16 points. Ukraine's results can approximately be compared with the results of one of the EU member states Poland. The smallest difference in ranking results (Table 1) between Poland and Ukraine was in 2014-2015 years, when Poland took $72^{\text {nd }}$ position, Ukraine $-81^{\text {st }}$ position. Nevertheless, one should pay attention to the steady deterioration of the Poland position by the analysed pillar. Ukraine is also well ahead of Serbia, which takes $108^{\text {th }}$ position in the ranking for 2014-2015 years.

The most stable positions in the ranking of countries by the pillar "Innovation" belong to such countries as Switzerland and Finland, which took first, second or third places during the analysed period. It shows the best integration of science, education and production in these countries.

Such countries as the USA and China have interesting results. They have although significantly outrun Ukraine in the ranking by the pillar "Innovation" during the analysed period 2010-2015 years, but with a continued deterioration in their positions.

General evaluation of the majority of subpillars of the "Innovations" pillar according to Table 2 is negative, although the change of the majority of subpillars in the last five years in percentage is positive. Such a situation is due to the fact that by the majority of subpillars the negative trend was overcome by Ukraine in the last analysed year 2014-2015. The negative results are displayed consistently only by one subpillar "Gov't procurement of advanced tech products", which is $-6.9 \%$. It illustrates the failure of Ukraine at the state level to support integration of science, education and production by the procurement of high-tech products.

General falling dynamics of the subpillar "Gov't procurement of advanced tech products" of Ukraine is presented in Figure 1.

As one can see, in the period from 2010 to 2015, Ukraine has worsened its position in the ranking of competitiveness by subpillar "Gov't procurement of advanced tech products", from the place 97 in 2012-2013 years to the place 123 in 2014-2015 years respectively. It should be noted that the time period 2013-2015 years was in the largest sociopolitical and socio-economic crisis in the history of Ukraine. It has greatly influenced the minimization of the state support of urgently needed integration of science, education and production.

Figure 2 shows that by the subpillar "Gov't procurement of advanced tech products" Ukraine (123rd place) is ahead of such a developed EU country as Italy (130th place). It is quite a surprising result.

Leading positions by this subpillar are occupied by such countries as Qatar, UAE, Malaysia, Singapore and Rwanda. Thus, in these countries, the state is the most interested in promoting establishment of high-tech industries and promotes integration of science, education and production. 
Table 1. Pillars of GCl - Innovation

\begin{tabular}{|c|c|c|c|c|c|c|c|c|c|c|c|}
\hline \multirow[b]{2}{*}{ Country } & \multicolumn{2}{|c|}{ 2010-2011 } & \multicolumn{2}{|c|}{ 2011-2012 } & \multicolumn{2}{|c|}{$2012-2013$} & \multicolumn{2}{|c|}{ 2013-2014 } & \multicolumn{2}{|c|}{ 2014-2015 } & \multirow{2}{*}{\begin{tabular}{|l}
$\Delta, \%$ \\
Change \\
for 5 \\
years
\end{tabular}} \\
\hline & $\begin{array}{c}\text { Rank } \\
\text { out of } \\
139^{*}\end{array}$ & Score ${ }^{* *}$ & $\begin{array}{c}\text { Rank } \\
\text { out of } \\
142^{*}\end{array}$ & $\underset{* *}{\text { Score }}$ & $\begin{array}{c}\text { Rank } \\
\text { out of } \\
144^{\star}\end{array}$ & $\underset{* *}{\text { Score }}$ & $\begin{array}{c}\text { Rank } \\
\text { out of } \\
148^{*}\end{array}$ & $\underset{* *}{\text { Score }}$ & $\begin{array}{c}\text { Rank } \\
\text { out of } \\
144^{*}\end{array}$ & $\underset{\star \star}{\text { Score }}$ & \\
\hline China & 26 & 3.92 & 29 & 3.92 & 33 & 3.85 & 32 & 3.89 & 32 & 3.91 & -0.26 \\
\hline Finland & 3 & 5.56 & 3 & 5.72 & 2 & 5.75 & 1 & 5.79 & 1 & 5.78 & 3.81 \\
\hline Poland & 54 & 3.31 & 58 & 3.23 & 63 & 3.25 & 65 & 3.24 & 72 & 3.26 & -1.53 \\
\hline Serbia & 88 & 2.93 & 97 & 2.90 & 111 & 2.81 & 112 & 2.85 & 108 & 2.89 & -1.38 \\
\hline Switzerland & 2 & 5.6 & 1 & 5.77 & 1 & 5.78 & 2 & 5.70 & 2 & 5.70 & 1.75 \\
\hline Ukraine & 63 & 3.11 & 74 & 3.11 & 71 & 3.16 & 93 & 3.03 & 81 & 3.16 & 1.58 \\
\hline United States & 1 & 5.65 & 5 & 5.57 & 6 & 5.50 & 7 & 5.37 & 5 & 5.49 & -2.91 \\
\hline
\end{tabular}

* Note: Ranks out of $\mathrm{N}$ economies.

${ }^{* *}$ Note: Scores measured on a 1-to-7 scale.

Table 2. Subpillars of GCl - Innovation

\begin{tabular}{|c|c|c|c|c|c|c|c|c|c|c|c|}
\hline \multirow[b]{2}{*}{ Subpillars of Ukraine } & \multicolumn{2}{|c|}{ 2010-2011 } & \multicolumn{2}{|c|}{ 2011-2012 } & \multicolumn{2}{|c|}{ 2012-2013 } & \multicolumn{2}{|c|}{ 2013-2014 } & \multicolumn{2}{|c|}{$2014-2015$} & \multirow{2}{*}{$\begin{array}{l}\Delta, \% \\
\text { Change } \\
\text { for } 5 \\
\text { years }\end{array}$} \\
\hline & $\begin{array}{c}\text { Rank } \\
\text { out of } \\
139^{*}\end{array}$ & $\underset{* \star}{\text { Score }}$ & $\begin{array}{c}\text { Rank } \\
\text { out of } \\
142^{*}\end{array}$ & $\underset{* *}{\text { Score }}$ & $\begin{array}{c}\text { Rank } \\
\text { out of } \\
144^{*}\end{array}$ & $\underset{* *}{\text { Score }}$ & $\begin{array}{c}\text { Rank } \\
\text { out of } \\
148^{*}\end{array}$ & $\underset{* *}{\text { Score }}$ & $\begin{array}{c}\text { Rank } \\
\text { out of } \\
144^{*}\end{array}$ & $\underset{* *}{\text { Score }}$ & \\
\hline Capacity for innovation & 37 & 3.5 & 42 & 3.4 & 58 & 3.3 & 100 & 3.2 & 82 & 3.6 & 2,78 \\
\hline $\begin{array}{l}\text { Quality for scientific } \\
\text { research institutions }\end{array}$ & 68 & 3.6 & 72 & 3.6 & 64 & 3.7 & 69 & 3.6 & 67 & 3.8 & 5,26 \\
\hline $\begin{array}{l}\text { Company spending on } \\
R \& D\end{array}$ & 69 & 3.0 & 75 & 3.0 & 104 & 2.7 & 112 & 2.7 & 66 & 3.1 & 3,23 \\
\hline $\begin{array}{l}\text { University-industry } \\
\text { collaboration in } R \& D\end{array}$ & 72 & 3.5 & 70 & 3.6 & 69 & 3.6 & 77 & 3.4 & 74 & 3.5 & 0,00 \\
\hline $\begin{array}{l}\text { Gov't procurement of } \\
\text { advanced tech products }\end{array}$ & 112 & 3.1 & 112 & 3.1 & 97 & 3.2 & 118 & 3.0 & 123 & 2.9 & $-6,90$ \\
\hline $\begin{array}{l}\text { Availability of scientists } \\
\text { and engineers }\end{array}$ & 53 & 4.3 & 51 & 4.3 & 25 & 4.8 & 46 & 4.5 & 48 & 4.3 & 0,00 \\
\hline $\begin{array}{l}\text { Utility patents per million } \\
\text { population } * \star \star\end{array}$ & 64 & 0.4 & 71 & 0.3 & 51 & 2.1 & 52 & 2.9 & 52 & 3.2 & 87,50 \\
\hline
\end{tabular}

* Note: Ranks out of $\mathrm{N}$ economies.

${ }^{* *}$ Note: Scores measured on a 1-to-7 scale.

${ }^{* * *}$ The United States Patent and Trademark Office

Source: Composed by the authors on the basis of WEF GCR (2010-2015)

The subpillar "University-industry collaboration in $R \& D$ " shows advantages of the industry partnering with universities (Fig. 3). In such a case, there are two potential benefits (Fey, Birkinshaw, 2005): (a) Universities tend to be more open, as the social norms in academia favor knowledge sharing rather than hoarding, and (b) any outflow of knowledge from the focal firm to the partnering organization is less sensitive in the case of partnering with universities, as universities are not potential competitors. 

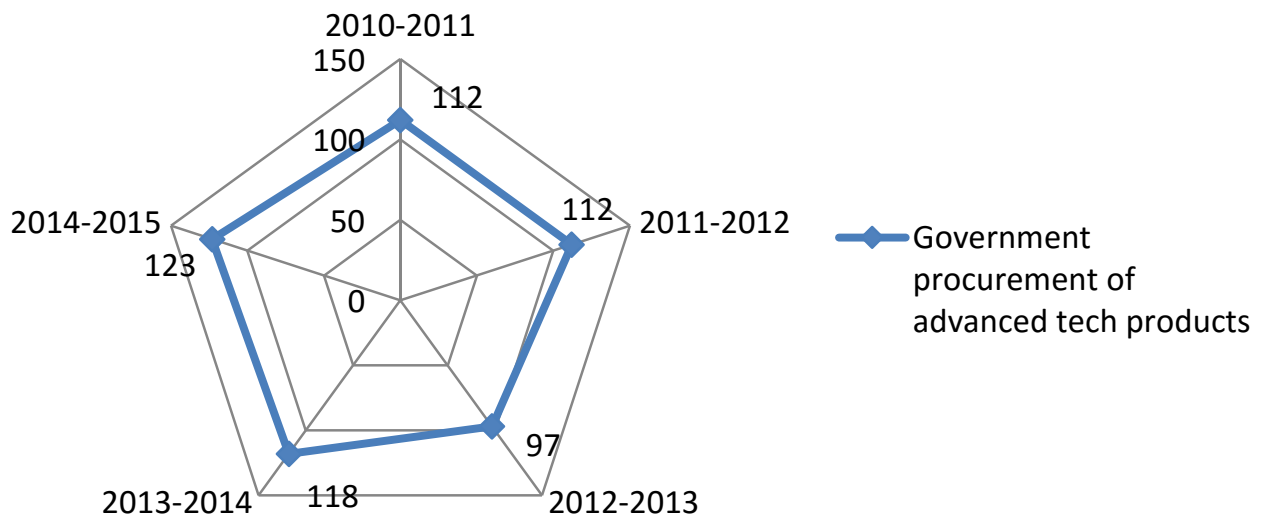

Fig.1. Dynamics of the Ukraine's ranks by the sub-pillar "Government procurement of advanced tech products" in 2010-2015

Source: Calculated by the authors on the basis of WEF GCR (2010-2015)

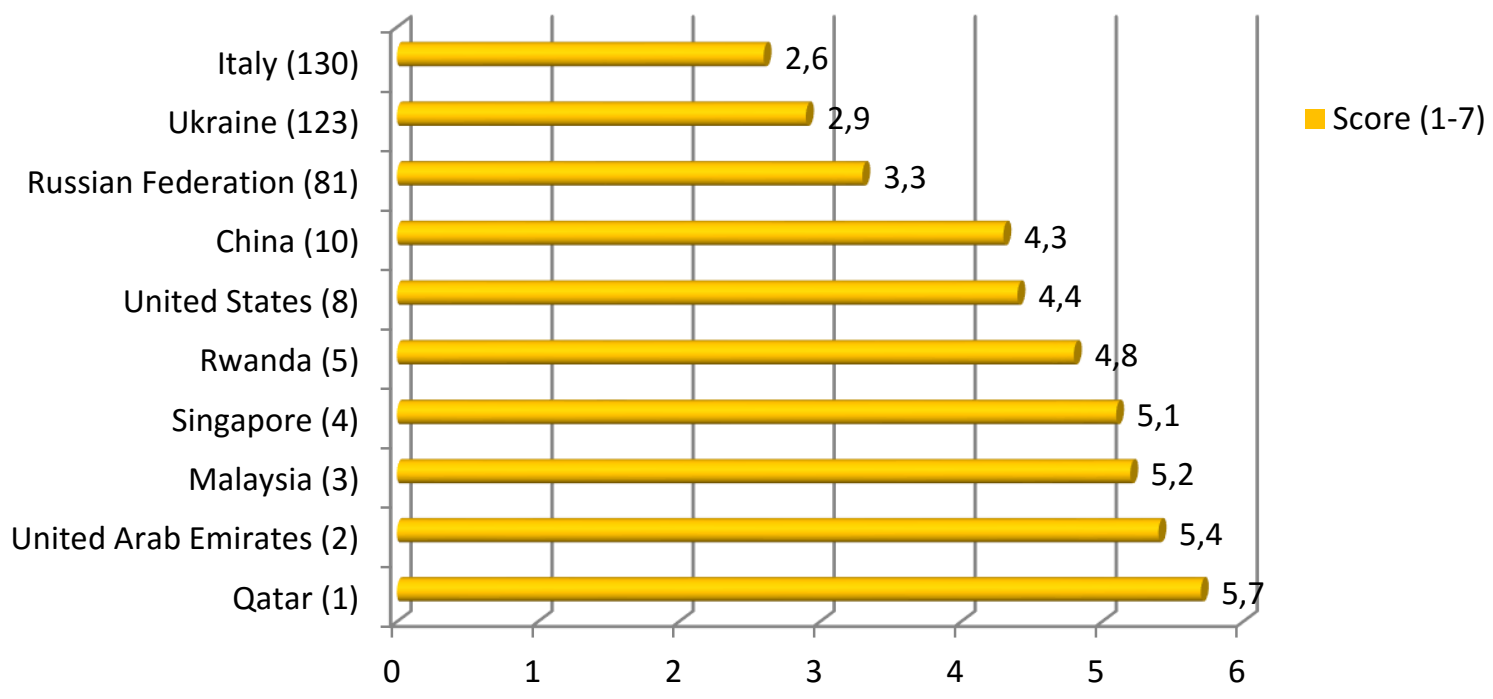

Fig.2. Dynamics of the several countries' ranks by the sub-pillar

"Government procurement of advanced tech products" in 2014-2015

Source: Calculated by the authors on the basis of (WEF GCR 2014-2015)

Data of the Global Competitiveness Index by the subpillar "University-industry collaboration in $R \& D$ " (Table 1) show that this indicator for Ukraine is relatively stable during the period 2010-2015. The most significant fall it suffered in the years 2013-2014, when Ukraine ranked 77 position (3.4 points). However, Figure 3 shows that even in the years 2014-2015 Ukraine improved its position and took 74 place, but it is 7 positions lower than the position of Russia ( 67 place) and 42 positions lower than the position of China (32 place).

The development processes feature analysis of integration of science, education and production in Ukraine shows that in the modern conditions there is kept the scientific sphere separation from the production needs; scientific research and development have weak identification in the innovative processes at the industrial enterprises. The main R\&D organization form is academic and industry research institutions, separated from the high school and the real economy sector. National integration processes undergo significant impact of negative factors that impede their positive development. They include: low interest in innovative production structures, their focus on maximizing profits in the short term; lack of the systemic legislation on integration, legal uncertainty of integration forms; low level of scientific research expences by the state and the 
economy private sector; low level of financing the integration process; imperfect infrastructure support of innovations; lack of effective mechanisms for economic incentives for the innovative activity; weak interaction between the science sectors.

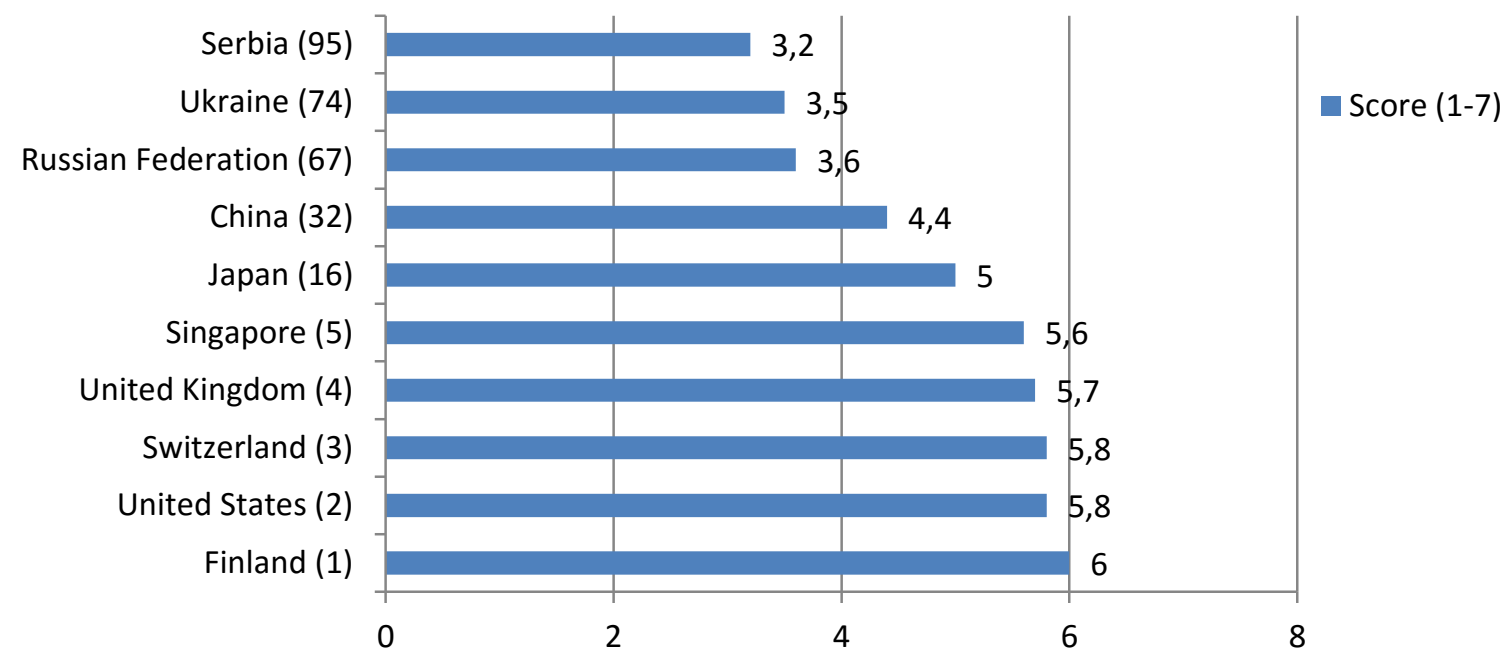

Fig. 3. Dynamics of the several countries' ranks by the sub-pillar

"University-industry collaboration in R\&D" in 2014-2015

Source: calculated by the authors on the basis of (WEF GCR 2014-2015)

We share the majority of scientists and professionals point of view who fairly include the following positions to major contemporary challenges and preconditions of deepening scientific, educational and productive interaction (Fedulova, 2009; Heyets, Semynozhenko, 2006; Mudraya, 2010):

- exhaustiveness of the national economy existing low structure opportunities, need for a substantial increase of its efficiency;

- economy becomes innovative, which is based on the new products creation, from the replicative one based on the production of large quantities of similar goods;

- dynamics of the economic development increasingly depends on the state of technological innovations development and implementation;

- the innovative process is not a result of one or several organizations activity, but of more significant in their number;

- change of ideas about the relationship between economic agents (a fundamentally new aspect becomes the combination of competition and cooperation, cooperation and rivalry);

- availability of powerful scientific-technical potential and the developed educational system of Ukraine, which are able to provide the economy by highly qualified personnel, modern scientific and technological developments on the condition of increasing the innovative interest from the production side.

Regarding the existing departmental, organizational and economic disunity of science, education and production in Ukraine, insufficient level of investment support of scientific and technological, and innovative activity, low innovative activity of industry, the measures are needed that will allow without significant financial investments rationally exploit potential and possibilities of research institutions, educational institutions and production in the sphere of training of highly qualified personnel, development and refinement of scientific-technical products to their commercial use.

Implementing new instruments of the financial support of integration processes and increasing the budgetary funds efficiency in the area of science can be made with the help of: the grants system development; optimization of the structure of budget expences on science in the direction of increasing the share of program-targeted funding under the state target scientific and scientifictechnical programs, government contracts for 
$R \& D$; developing mechanisms of interaction between participants in the innovation process in a model of public-private partnership; implementation of integrated, multidisciplinary researches by organizations from various sectors of science; targeted financing of effective bilateral and tripartite organizational forms of integration of science, education and production.

\section{PUBLIC MANAGEMENT OF INTEGRATION OF EDUCATION, SCIENCE AND PRODUCTION IN THE CONTEXT OF SYNERGETIC PARADIGM}

Knowledge economy as the main factor of the economic development determines an individual, the intellectual factor, human capital and the creative potential. In turn, the human potential is determined by the level of knowledge, skills, competencies and, most importantly, the ability of people to interact coherently in the processes of production and realization of the social product, i.e. ability to generate synergetic effects in the social development. The majority of modern scholars think that synergy of interactions of scientific, innovation and technology, human, investment and business potentials is the alternative to competition as the main driving force of the economic development (Fedulova, 2009; Heyets, Semynozhenko, 2006; Roco, Bainbridge, 2013). In addition, the synergetic action of driving forces of the economic development at the global level, even in the short term, is unpredictable, and is poorly predictable at the national level, in the medium term, and is not predictable in the long run. The uncertainty in the economic development increases the social and economic risks in the government programs adoption and implementation.

The use of an interdisciplinary approach in the research of social transformations, openness and non-linearity of the national economy development, irreversibility of institutional changes and macroeconomic processes, which are characterized by instability as different from equilibrium, cause an objective need for using the synergetic approach to strategic public management.
It is important to evaluate synergetic effects in complex socio-economic systems as a result of the cooperative interaction between its components, which changes the system quality, the trajectory of its development. The synergetic effects formation in such systems is provided as a result of the system synthesis of technical, technological, organizational, economic, social, environmental, managerial factors including the constantly changing temporal and spatial factors (Ravinskij, 2006).

The set of accumulated in Ukraine financial, economic, infrastructural, technological, environmental, social and managerial problems has led to a complete deregulation of the national economy and has put forward the economic science a need for management strategies of the socio-economic development, which would have made it possible to guide actively the selfcontained own movement with minimal losses. One of the strategic directions is to modernize the socio-economic system based on the use of new technologies and innovations in all spheres of human activity, synchronization of nature, economy and human development. The defining element in the system of public anti-crisis management of the economy of Ukraine should be determined by the balance of human and technological development, which will adjust the target priorities of economic restructuring on the basis of innovative changes, decide on macroeconomic multiplier effects of synergetic effect of their interaction synchronization. As the main strategic task for implementing the national economic policy of Ukraine it is proposed to form the system of mechanisms of the technological development and social policy interaction based on creating a modern balanced economic complex with a strong corporate and cooperation framework, which will ensure a tight cooperation of local entities and beneficial integration into the world economy (Table. 3). The new national concept should be based not only on leadership and management, but also on organization. In the complex of instruments and mechanisms of formation and implementation of national concepts of innovative and technological development the special place should be given to Foresight-methodology.

It is the basis of coordination of priorities of innovative and technological development in the 
framework of a constructive dialogue of the state and society, involvement of wide business circles in their realization, formation of permanent "playgrounds" of interaction between science, education and production. The nonlinear character of the economy behaviour becomes the increasingly obvious fact. There is a need to develop new methods of public management based on the program-targeted direction traditions and distributed on the basis of considering the synergetic paradigm of development.

Table 3. The system of public management of balancing human and technological development

\begin{tabular}{|c|c|c|c|c|}
\hline Elements & \multicolumn{4}{|c|}{ Contents } \\
\hline Provision & Program-targeted & Organizational-economic & $\begin{array}{l}\text { Informational, } \\
\text { predictive and } \\
\text { analytical }\end{array}$ & Institutional \\
\hline Mechanisms & $\begin{array}{l}\text { Scientific and } \\
\text { technological } \\
\text { Foresight; a } \\
\text { dialogue of the } \\
\text { state, business, } \\
\text { science }\end{array}$ & $\begin{array}{l}\text { Protection of intellectual } \\
\text { property; technology } \\
\text { transfer; accreditation of } \\
\text { innovative products; } \\
\text { motivation of } \\
\text { modernization; sanitation } \\
\text { of obsolete production; } \\
\text { formation of innovative } \\
\text { management } \\
\text { competencies }\end{array}$ & $\begin{array}{l}\text { Technological } \\
\text { forecasting } \\
\text { (global, systemic); } \\
\text { monitoring of } \\
\text { effects; expertises } \\
\text { of consequences }\end{array}$ & $\begin{array}{l}\text { Government } \\
\text { procurement; public- } \\
\text { private partnership; } \\
\text { business angels; } \\
\text { incentives (tax } \\
\text { breaks, loans, } \\
\text { subsidies) }\end{array}$ \\
\hline Instruments & $\begin{array}{l}\text { Technological } \\
\text { platforms; road } \\
\text { maps; } \\
\text { benchmarking; } \\
\text { priority contours of } \\
\text { technologies; } \\
\text { technological } \\
\text { framework } \\
\text { conditions }\end{array}$ & $\begin{array}{l}\text { Tenders; technological } \\
\text { parks; technopolises; } \\
\text { sociopolises; clusters; } \\
\text { business incubators of } \\
\text { innovative enterprises }\end{array}$ & $\begin{array}{l}\text { Circular of } \\
\text { accreditation; } \\
\text { catalogue of } \\
\text { scientific and } \\
\text { technological } \\
\text { achievements }\end{array}$ & $\begin{array}{l}\text { Contracts; } \\
\text { agreements; } \\
\text { concessions; joint } \\
\text { ventures; leasing; } \\
\text { outsourcing; } \\
\text { franchise }\end{array}$ \\
\hline Results & $\begin{array}{l}\text { Paradigm; } \\
\text { concept; strategy; } \\
\text { programs; policy }\end{array}$ & 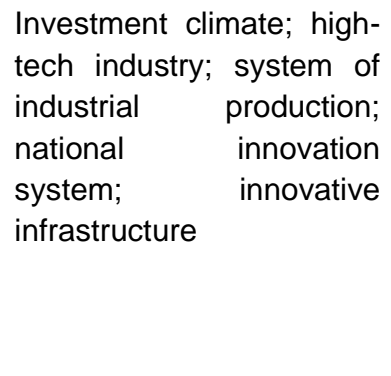 & $\begin{array}{l}\text { Assessment } \\
\text { system of } \\
\text { potential; } \\
\text { communication } \\
\text { platform; } \\
\text { information system } \\
\text { of popularizing }\end{array}$ & $\begin{array}{l}\begin{array}{l}\text { Innovative } \\
\text { of }\end{array} \\
\text { importance; } \\
\text { national } \\
\text { of financial support } \\
\text { (venture capital, } \\
\text { state } \\
\text { investment funds); } \\
\text { corporate and co- } \\
\text { operative framework }\end{array}$ \\
\hline
\end{tabular}

Source: developed by the authors

Recognition in the system of anti-crisis public management of the synergetic paradigm that takes into account variability, alternativeness of the modern market economic systems development with a lot of bifurcation points will solve the strategic task of reproducing the national system with involving the business elite in the regulatory processes of human and technological development on the basis of public-private partnerships.
The strategy of balancing human and technological development of Ukraine should be based on transition from balancing between alternative objectives of social security and economic growth - from integration of improving the welfare of the nation and each citizen to development of the dynamically developing competitive national economy. The main strategic goals should be: providing the advanced development of human capital as the key competitive factor in the modern economy; the fullest development and use of national intellectual 
and entrepreneurial potential through integration of science, education and production; spreading social effects of the economic growth in the form of improving real income and purchasing power; strengthening social protection; improving living conditions.

The synergetic approach to the methodology of public management gives a chance for a modern interpretation of such categories as "crisis", "uncertainty", "space", "time", "order", "chaos", "order parameter", "forecasting", "risks", "irreversibility", "nonlinear dynamics", "complexity" and etc. A synergy of science allows paying attention to such phenomena, which are in our lives, in the scientific revolution, in the conceptual apparatus, and taking into account in developing mechanisms, methods and management tools.

Effectiveness of public regulation and strategic management will not be achievable in the absence of the reasonable value choice, a clear definition of purpose, vision and ways of effective mechanisms to achieve the set objectives. Without appropriate strategisation of the national economy there will be a few drifting controlled state, a permanent dependence on volatility of external factors and external geopolitical interests.

\section{CONCLUSIONS}

Integration of universities, research organizations and high tech enterprises should ideally be complex, combine all known areas of scientific, educational and innovative activity, and create the appropriate synergetic effect. Ultimately, it should be directed to formation and development of a certain industrial and economic cluster, which is a priority for the region and / or the industry. The cluster, which is formed and developed, should be profile oriented in the direction of activity and innovation-oriented by its nature and the forms of interaction of integration processes participants.

To enhance the scientific research effectiveness in Ukraine it is advisable:

to create at the national level a Coordinating Centre for Research of all subjects' scientific activity: universities, structural units of National Academy of Sciences of Ukraine, branch academies, the sector of "production" science;

- to create a network of scientific parks that combine the main participants' interests: high tech companies, academic departments, university departments and faculties, researchers and businessmen.

In developing the strategy and the policy for the science development in Ukraine today the following priorities should be considered:

- concentration of resources on conducting fundamental and applied researches in areas where Ukraine has the considerable scientific, technological and industrial potential;

implementation of the program-targeted approach to all scientific sphere sectors financing;

- implementation of market mechanisms of supporting new technologies, promoting small and medium enterprises in scientific and technological development;

bringing the system of legal protection of intellectual property in accordance with international standards and introducing intellectual property into production;

development and implementation of modern information technologies.

Integration of science, education and production is the important instrument of public management of balancing human and technological development in the synergetic paradigm. Adding the large-scale continuous implementation of innovations in technology, education, science to situational, organizational and investment development factors is able to bring Ukraine in 2050 to the upper limit of social productivity of advanced countries. In turn, it is possible if to balance human and technological development due to the synergetic effect.

The key element of coordinating research activities in the fields of science and education in the state is the monitoring researches. It should also be developed the methodological basis of evaluating the scientific research performance in the field of science and education by developing the rating assessment systems and enriching the existing complex performance indicators and criteria of the integrative nature.

Coordination of scientific activity in the fields of science and education will contribute to its effective implementation and operational control over execution of scientific and research programs, exclusion of small topics, duplication, and repetition of the scientific projects. It should be 
a set of interrelated scientific and organizational, socio-economic and legal impacts on autonomous creative teams and individual researchers working in this field with the aim of implementing harmonious interests of the state, society, economy, universities, research institutes (organizations) and scientist in achieving maximum effectiveness of efforts and means to achieve the objectives of scientific and research work.

\section{WORKS CITED}

Amosha, O.I., Vishnevskiy, V.P., \& Zbarazska, L.A. (2012). Neoindustrialization and new industrial policy of Ukraine [Neoindustrializatsia $i$ novaja promyshlennaja politika Ukrainy]. Economy of Insutry [Ekonomika promyshlennosti], Vol. 57-58, No. 1-2, Pp. 3-32.

Bavykhin, G.A. (2003). Management of education development: organizational and economical aspect [Upravlenie razvitiem obrazovania: organizatsionno-ekonomicheskij aspect]. Moscow, Ekonomika. 428 p.

Bazhal, I. (2009) Technological Determinism of the Knowledge Economy Building in Transitive Countries. KSI Transactions on Knowledge Society. A publication of the Knowledge Society Institute. Vol. II, No.3, Pp. 13-16.

Bulanova-Toporkova M.V. (Ed.). (2002). Pedagogy and psychology of high school: Textbook. Rostov-na-Donu, Fenix, $544 p$

Grodskyj, S.V. (2012). European scoreboard of the innovative development and Ukraine [Evropejske tablo innovatsijnogo rozvytku ta Ukraina] // Innovative economy, No.12, Pp. 28-31.

Chiswrok, B.R. (1974). Income inequality: Regional analysis within a human capital Framework. N.Y. XVI. P. 30.

Denison, E.F. (1967). Why Growth Rates Differ: Post-War Experience in Nine Western Countries. Brookings Institute, Washington D.C. 494 p.

Fedulova, L.I. (2009). Knowledge economy [Ekonomika znan]: handbook [for students of HEE]. NAS of Ukraine; Insitute for economics and forecasting of NAS of Ukraine. Kyiv, PPC "Ekvpres", 600 p.

Fey, C., \& Birkinshaw, J.M. (2005). External knowledge sourcing, governance mode, and R\&D performance. Journal of Management, 31(4), Pp. 597-613.

Heyets, V.M., \& Semynozhenko, V.P. (2006). Innovative perspectives of Ukraine [Innovatsijni perspektyvy Ukrainy]. Kharkiv, Konstanta, $272 p$.

Ivanov, V.N., Ivanov, A.V., \& Doronin A.O. (2002). Management paradigm of the XXI century [Upravlencheskaja paradigma XXI veka]: training guide for HEE. Tom 1. Moscow, MSIM, $180 p$

Kostyuk, S.G. (2011). On integration of the educational process at the university and innovative activity [Ob integratsii obrazovatelnogo protsessa $v$ vuze $i$ innovatsionnoj dejatelnosti]. [In:] Innovative processes and corporate management [Innovatsionnyje protsessy $i$ korporativnoje upravlenie]: Collection of articles of the III International distance scientific and pratical conference; V.V. Apanasovich (ed.). BGU, Institute of business and management of technologies, Minsk, National Library of Belarus, Part 1, 312 p., Pp. 252256.

Mudraya, O.V. (2010). Analysis of the domestic practice of interaction between science, education and business [Analiz otechestvennoj praktiki vzaimodejstvia nauki, obrazovania i biznesa]. [In:] Mechanisms of managing the socio-economic systems development [Mekhanizmy upravlinnia rozvytkom sotsialnoekonomichnykh system]: monograph; O.V. Martiakova (ed.). Donetsk, SHEE "DonNTU”, 688 p.

OECD. (1996). Lifelong Learning for All. Paris: OECD.

Ravinskij, R.V. (2006). Synergetics and development processes of complex systems [Sinergetika i protsesy razvitia slozhnykh system]. Issues of Philosophy [Voprosy filosofii], No. 2, Pp. 162-169.

Roco, M.C., \& Bainbridge, W.S. (2013). The new world of discovery, invention, and innovation: convergence of knowledge, technology, and society. Journal of Nanoparticle Research, No.15.9, Pp. 1-17.

Shultz, T. (1960). Capital Formation by Education // Journal of Political Economy. Vol. 68.

Twiss, B. (1980). Managing Technological Innovation, $2^{\text {nd }}$ ed. London, Longman.

World Economic Forum. (2015, December 12). The Global Competitiveness Report 2010-2011. http://www3.weforum.org/docs/WEF_GlobalCompetitivenessReport_2010-11.pdf 
World Economic Forum. (2015, December 12). The Global Competitiveness Report 2011-2012. http://www3.weforum.org/docs/WEF_GCR_Report_2011-12.pdf

World Economic Forum. (2015, December 12). The Global Competitiveness Report 2012-2013. http://www3.weforum.org/docs/WEF_GlobalCompetitivenessReport_2012-13.pdf

World Economic Forum. (2015, December 12). The Global Competitiveness Report 2013-2014. http://www3.weforum.org/docs/WEF_GlobalCompetitivenessReport_2013-14.pdf

World Economic Forum. (2015, December 12). The Global Competitiveness Report 2014-2015. http://www3.weforum.org/docs/WEF_GlobalCompetitivenessReport_2014-15.pdf

Received for publication: $\quad 10.01 .2016$

Revision received: $\quad 05.02 .2016$

Accepted for publication: $\quad 12.02 .2016$

\section{How to cite this article?}

Style - APA Sixth Edition:

Emelyanenko, L., \& Shkoda, T. (2016, July 15). Integration of education, science and production in synergetic paradigm of public management. (Z. Čekerevac, Ed.) MEST Journal, 4(2), 64-76. doi:10.12709/mest.04.04.02.07

Style - Chicago Sixteenth Edition:

Emelyanenko, Larysa, and Tetiana Shkoda. 2016. "Integration of education, science and production in synergetic paradigm of public management." Edited by Zoran Čekerevac. MEST Journal (MESTE) 4 (2): 64-76. doi:10.12709/mest.04.04.02.07.

Style - GOST Name Sort:

Emelyanenko Larysa and Shkoda Tetiana Integration of education, science and production in synergetic paradigm of public management [Journal] // MEST Journal/ ed. Čekerevac Zoran. Belgrade : MESTE, July 15, 2016. - 2 : Vol. 4. - pp. 64-76.

Style - Harvard Anglia:

Emelyanenko, L. \& Shkoda, T., 2016. Integration of education, science and production in synergetic paradigm of public management. MEST Journal, 15 July, 4(2), pp. 64-76.

Style - ISO 690 Numerical Reference:

Integration of education, science and production in synergetic paradigm of public management. Emelyanenko, Larysa and Shkoda, Tetiana. [ed.] Zoran Čekerevac. 2, Belgrade : MESTE, July 15, 2016, MEST Journal, Vol. 4, pp. 64-76. 